\title{
Effects of Pumpkin (Cucurbita maxima Duch.) Fiber on Physicochemical Properties and Sensory Characteristics of Chicken Frankfurters
}

\author{
Yun-Sang Choi, Hyun-Wook Kim¹, Ko-Eun Hwang ${ }^{1}$, Dong-Heon Song ${ }^{1}$, Jae-Hyun Park ${ }^{1}$, \\ Soo-Yeon Lee ${ }^{1}$, Min-Sung Choi ${ }^{1}$, Ji-Hun $\mathrm{Choi}^{2}$, and Cheon-Jei Kim ${ }^{1 *}$ \\ Food and Biological Resources Examination Division, Korean Intellectual Property Office, Daejeon 302-701, Korea \\ ${ }^{1}$ Department of Food Science and Biotechnology of Animal Resources, Konkuk University, Seoul 143-701, Korea \\ ${ }^{2} C J$ Only One R \& D Center, CJ Cheiljedang, Seoul 152-051, Korea
}

\begin{abstract}
The effects of dietary fiber extracted from pumpkin (pumpkin fiber) on physicochemical properties, textural properties, and sensory characteristics of chicken frankfurters were investigated. Chicken frankfurter was supplemented with pumpkin fiber at levels of $0,1,2,3$, and $4 \%$. Adding different levels of pumpkin fiber affected the proximate composition of the chicken frankfurters $(p<0.05)$, except for protein content. In addition of different levels of pumpkin fiber influenced the physicochemical and textural properties of the chicken frankfurters $(p<0.05)$. The yellowness, viscosity, and hardness were higher in chicken frankfurters samples containing pumpkin fiber than those in the control $(p<0.05)$. The results showed that chicken frankfurter samples with higher pumpkin fiber levels had lower lightness values $(p<0.05)$, as well as less cooking loss, emulsion stability, and lower color scores $(p<0.05)$ compared to those control without pumpkin fiber treatment. The chicken frankfurters with $2 \%$ and $3 \%$ pumpkin fiber had higher overall acceptability than that of the control $(p<0.05)$. The results show that adding pumpkin fiber produced acceptable chicken frankfurters and improved their quality characteristics.
\end{abstract}

Key words: pumpkin fiber, chicken frankfurters, physicochemical properties, sensory characteristics, emulsion stability

\section{Introduction}

Chicken meat and chicken products are very popular among consumers and provide an excellent source of animal protein. Many chicken meat products are currently sold on the market, such as cured thigh meat and fillet, jerky, patties, sausages, and nuggets (Abiola et al., 2004; Choi et al., 2010b). Chicken is selected due to its comparatively low-fat content, high-nutritional value, and lowcost of manufacture (Hwang et al., 2011).

Frankfurters are one of the oldest known forms of processed meat products and have been used widely around the world. Frankfurters may contain up to $30 \%$ animal fat (Choi et al., 2010a). High animal fat content in daily diets are related to high blood cholesterol levels and undesired weight gain because of excess calories associated with diseases (Chin et al., 2004; Choi et al., 2009, 2011; Lee et al., 2008; Turhan et al., 2005). Dietary fat content is sig-

*Corresponding author: Cheon-Jei Kim, Department of Food Science and Biotechnology of Animal Resources, Konkuk University, Seoul 143-701, Korea. Tel: 82-2-450-3684, Fax: 82-2444-6695, E-mail: kimcj@konkuk.ac.kr nificantly correlated with coronary heart disease, obesity, and cancer (Choi et al., 2008; Choi et al., 2010c; Grigelmo-Miguel et al., 1999; Lee et al., 2008). For these reasons, meat technologists have focused on developing new technologies to add functional materials such as dietary fiber. These functional materials include rice bran fiber, chestnut peel powder, kimchi fiber, lemon albedo fiber, sea tangle fiber, oat fiber, carrageenan, and oatmeal fiber (Choi et al., 2012; Fernández-Ginés et al., 2004; Hughes et al., 1997; Lee et al., 2008; Yang et al., 2007), which have been used to improve meat product quality.

Dietary fiber is a functional material and plays an important role in the human diet. Fiber has been added to various meat products to counter problems caused by high animal fat. Thus, dietary fiber has been ascribed a steadily increasing role in health and well-being. Moreover, dietary fiber included in meat products improves emulsion stability, water holding capacity, apparent viscosity, and textural properties (Aleson-Carbonell et al., 2003; Choi et al., 2009; Choi et al., 2010c; Lee et al., 2008). Some researchers have prepared meat products with added dietary fiber to help improve textural properties and sensory characteristics (Choi et al., 2010a; Choi 
et al., 2012; Fernández-Ginés et al., 2004; Luruena-Martinez et al., 2004; Shand, 2000). Adding dietary fiber to reduced-fat and low-fat meat products enhances rheological properties and stability (Choi et al., 2010b; Choi et al., 2010c; Fernández-Ginés et al., 2004; Lee et al., 2008; Vural et al., 2004).

Pumpkin belongs to the family Cucurbitaceae. Pumpkin is a squash fruit most commonly orange in color when ripe and has been used traditionally both as human and animal food. Pumpkins are a popular food in several countries, as they have provide multiple health benefits such as vitamins $\left(\mathrm{A}, \mathrm{B}_{1}, \mathrm{~B}_{2}\right.$, and $\left.\mathrm{C}\right)$, minerals ( $\mathrm{Fe}, \mathrm{Ca}, \mathrm{Na}$, $\mathrm{K}, \mathrm{Mg}$, and $\mathrm{P}$ ), $\beta$-carotene, and dietary fiber (Lee et al., 2010). In particular, pumpkin is a rich natural source of protein and dietary fiber (de Escalada Pla et al., 2007; Heo et al., 1998; Lee et al., 2005). Pumpkin has experienced attention in recent years because of its nutritional and health protective effects (Caili et al., 2007). Some researchers reported that they have addressed various food containing pumpkin powder (Lee and Joo, 2007; Lee et al., 2005; Woo et al., 2006). However, no research has been carried out on the direct incorporation of pumpkin fiber into meat products.

Therefore, the objective of this study was to investigate the effects of dietary fiber extracted from pumpkin on $\mathrm{pH}$, color, cooking loss, emulsion stability, texture profile analysis, viscosity, and sensory characteristics of chicken frankfurters.

\section{Materials and Methods}

\section{Preparation and processing of the pumpkin fiber extract}

Dietary fiber was extracted using the modified AOAC enzymatic-gravimetric method (AOAC, 2000). Pumpkin (Cucurbita maxima Duch.) was obtained from E-mart, Seoul, Korea. The pumpkin was gelatinized with $0.6 \%$ termamyl (heat stable alpha-amylase) at $95^{\circ} \mathrm{C}$ for $1 \mathrm{~h}$ to remove starch, followed by filtration. The residue was then washed three times with four volumes of heated water $\left(100^{\circ} \mathrm{C}\right)$ and allowed to equilibrate to room temperature $\left(20^{\circ} \mathrm{C}, 6 \mathrm{~h}\right)$. The residue was then washed with $99.9 \%$ ethanol (preheated to $60^{\circ} \mathrm{C}$ ), followed by filtration. The residue was dried $\left(55^{\circ} \mathrm{C}\right)$ overnight in an air oven and then cooled. The pumpkin fiber (moisture content, $7.82 \%$; fat content, $4.83 \%$; protein content, $12.28 \%$; ash content, $6.67 \%$; dietary fiber content, $58.34 \% ; L^{*}$-value, $78.81 ; a^{*}$ value, $1.30 ; b^{*}$-value, $\left.62.69 ; \mathrm{pH}, 6.74\right)$ was then placed in polyethylene bags, vacuum packaged using a vacuum packaging system (FJ-500XL, Fujee Tech, Korea) and stored at $4^{\circ} \mathrm{C}$ until used for product preparation.

\section{Chicken frankfurter preparation and processing}

Fresh chicken breast meat (M. pectoralis major) and pork back fat (moisture $12.61 \%$, fat $85.64 \%$ ) were purchased from a local processor. The reason for using chicken breast meat is the relatively low cost of production, low fat content, and high nutritional value. The chicken meat and pork fat were initially ground through an 8-mm plate. The ground tissue was then placed in polyethylene bags, vacuum sealed using a vacuum packaging system (FJ-500XL, Fujee Tech, Korea), and stored at $0^{\circ} \mathrm{C}$ until required for product preparation. Five different chicken meat batters were produced, and the experimental design and compositions are given in Table 1. The first meat batter served as the control and was prepared with $25 \%$ pork back fat without pumpkin fiber. The following combinations of back fat and pumpkin fiber were used; T1: $25 \%$ pork back fat and 1\% pumpkin fiber; T2: $25 \%$ pork back fat and 2\% pumpkin fiber; T3: $25 \%$ pork back fat and 3\% pumpkin fiber; T4: $25 \%$ pork back fat and $4 \%$ pumpkin fiber. Chicken meat was homogenized, ground for $1 \mathrm{~min}$ in a silent cutter (Cutter Nr-963009, Hermann Scharfen GmbH \& Co, Germany), then chilled in ice water $\left(2^{\circ} \mathrm{C}\right) . \mathrm{NaCl}(1.4 \%)$, sodium tripolyphosphate $(0.5 \%)$, isolated soy protein $(1.0 \%)$, sorbitol $(0.7 \%)$, monosodium glutamate $(0.03 \%)$, onion powder $(0.05 \%)$, garlic powder $(0.05 \%)$, and ginger powder $(0.05 \%)$ were added to the meat and mixed for $1 \mathrm{~min}$. Pumpkin fiber

Table 1. Chicken frankfurter formulas prepared with different pumpkin fiber ratios

\begin{tabular}{lccccc}
\hline \hline \multicolumn{1}{c}{ Ingredients } & Control $^{1)}$ & T1 & T2 & T3 & T4 \\
\hline Chicken breast & 50 & 50 & 50 & 50 & 50 \\
Pork back fat & 25 & 25 & 25 & 25 & 25 \\
Ice & 25 & 25 & 25 & 25 & 25 \\
\hline Total & 100 & 100 & 100 & 100 & 100 \\
\hline Pumpkin fiber ${ }^{2)}$ & - & 1.0 & 2.0 & 3.0 & 4.0 \\
NaCl & 1.4 & 1.4 & 1.4 & 1.4 & 1.4 \\
Sodium tripolyphosphate & 0.5 & 0.5 & 0.5 & 0.5 & 0.5 \\
Isolated soy protein & 1.0 & 1.0 & 1.0 & 1.0 & 1.0 \\
Sorbitol & 0.7 & 0.7 & 0.7 & 0.7 & 0.7 \\
Monosodium glutamate & 0.03 & 0.03 & 0.03 & 0.03 & 0.03 \\
Onion powder & 0.05 & 0.05 & 0.05 & 0.05 & 0.05 \\
Garlic powder & 0.05 & 0.05 & 0.05 & 0.05 & 0.05 \\
Ginger powder & 0.05 & 0.05 & 0.05 & 0.05 & 0.05 \\
\hline
\end{tabular}

${ }^{1)}$ Control, chicken frankfurter without pumpkin fiber; T1, chicken frankfurter with $1 \%$ pumpkin fiber; T2, chicken frankfurter with $2 \%$ pumpkin fiber; $\mathrm{T} 3$, chicken frankfurter with $3 \%$ pumpkin fiber; T4, chicken frankfurter with $4 \%$ pumpkin fiber

${ }^{2)}$ Pumpkin: Cucurbita maxima Duch 
and pork back fat were added after $3 \mathrm{~min}$. The meat batters were homogenized for $5 \mathrm{~min}$. A temperature probe (Kane-May, KM330, UK) was used to monitor the temperature of the emulsion, which was maintained at $<10^{\circ} \mathrm{C}$ throughout batter preparation. After emulsification, the meat batter was stuffed into collagen casings (\#240, NIPPI Inc., Japan; approximate diameter, $25 \mathrm{~mm}$ ) using a stuffer (Stuffer IS-8, Sirman, Italy). The meat batter was then heated to $75^{\circ} \mathrm{C}$ for $30 \mathrm{~min}$ in a water bath (model 10101, Dae Han Co, Korea), and then the cooked meat batter was cooled in cold water $\left(15^{\circ} \mathrm{C}\right)$. This procedure was performed in triplicate for each chicken frankfurters type.

\section{Proximate composition}

Composition properties of the chicken frankfurters were determined using AOAC methods (2000). Moisture content $(950.46 \mathrm{~B})$ was calculated by weight loss after 12 $\mathrm{h}$ of drying at $105^{\circ} \mathrm{C}$ in a drying oven (SW-90D, Sang Woo Scientific Co., Korea). Fat content (960.69) was determined by the Soxhlet method with a solvent extraction system (Soxtec Avanti 2050 Auto System, Foss Tecator AB, Höganas, Sweden), and protein content (981.10) was determined by the Kjeldahl method with an automatic Kjeldahl nitrogen analyzer (Kjeltec 2300Analyzer Unit, Foss Tecator $\mathrm{AB}$ ). Ash was determined according to the AOAC method 920.153 (muffle furnace).

\section{pH}

The $\mathrm{pH}$ values of each batter and frankfurter were measured in a homogenate prepared with $5 \mathrm{~g}$ of sample and distilled water $(20 \mathrm{~mL})$ using a $\mathrm{pH}$ meter (Model 340, Mettler-Toledo GmbH, Switzerland). All determinations were performed in triplicate.

\section{Color measurements}

The color of each batter and frankfurter was determined using a colorimeter (Minolta Chroma meter CR-210, Minolta Ltd., Osaka, Japan; illuminate C, calibrated with a white plate, $L^{*}=+97.83, a^{*}=-0.43$, and $b^{*}=+1.98$ ). Seven measurements for each of five replicates were obtained. Lightness (CIE $L^{*}$-value), redness (CIE $a^{*}$-value), and yellowness (CIE $b^{*}$-value) values were recorded.

\section{Cooking loss}

The meat batter was stuffed into casings (initial weight) after heat processing at $75^{\circ} \mathrm{C}$ for $30 \mathrm{~min}$, and cooked samples were cooled to room temperature at $21^{\circ} \mathrm{C}$ for $3 \mathrm{~h}$. After cooling, the cooked meat batter was weighed, and cooking loss was calculated from the weights.
Cooking loss (g/100 g)

$=[$ weight of raw meat batter $(\mathrm{g})-$ weight of cooked meat batter $(\mathrm{g})) /$ weight of raw meat batter $(\mathrm{g})] \times 100$

\section{Emulsion stability}

The chicken meat batter samples were analyzed for emulsion stability using the method of Blouka and Honikel (1992) with the following modifications. Pre-weighed graduated glass tubes were filled with batter at the middle of a 15 mesh sieve. The glass tubes were closed and heated for $30 \mathrm{~min}$ in a boiling water bath to a core temperature of $75 \pm 1^{\circ} \mathrm{C}$. After cooling to approximately $4^{\circ} \mathrm{C}$ to facilitate fat and water layer separation, the water and fat separated in the bottom of each graduated glass tube were measured and calculated (Choi et al., 2009).

Water exudation $(\mathrm{mL} / \mathrm{g})$

$=[$ the water layer $(\mathrm{mL}) /$ weight of raw meat batter $(\mathrm{g})] \times 100$

Fat exudation $(\mathrm{mL} / \mathrm{g})$

$=[$ the fat layer $(\mathrm{mL}) /$ weight of raw meat batter $(\mathrm{g})] \times 100$

\section{Apparent viscosity}

Chicken meat emulsion batter viscosity was measured in triplicate with a rotational viscometer (Hakke Viscotester 550, Thermo Electron Corp., Germany) set at $10 \mathrm{rpm}$. A standard cylinder sensor (SV-2) was positioned in a $25 \mathrm{~mL}$ metal cup filled with batter and allowed to rotate for $30 \mathrm{~s}$ under a constant shear rate $\left(\mathrm{s}^{-1}\right)$ before each reading was taken. Apparent viscosity values in centipoises were obtained. The temperature of each sample at the time $\left(18 \pm 1^{\circ} \mathrm{C}\right)$ of viscosity testing was also recorded.

\section{Texture profile analysis}

The texture profile analysis (TPA) was conducted using the method of Choi et al. (2010b) at room temperature with a texture analyzer (TA-XT2i, Stable Micro Systems Ltd., England). The chicken meat batter was stuffed into casings followed by heating $\left(75 \pm 1^{\circ} \mathrm{C}\right.$ for $\left.30 \mathrm{~min}\right)$, and the cooked samples were cooled to room temperature at $21^{\circ} \mathrm{C}$ for $30 \mathrm{~h}$. The samples were allowed to equilibrate to room temperature. Samples were taken from the central portion of each chicken frankfurter type. The texture analysis conditions were as follows: pre-test speed, $2.0 \mathrm{~mm} / \mathrm{s}$; posttest speed, $5.0 \mathrm{~mm} / \mathrm{s}$; maximum load, $2.0 \mathrm{~kg}$; head speed, $2.0 \mathrm{~mm} / \mathrm{s}$; distance, $8.0 \mathrm{~mm}$; force, $5.0 \mathrm{~g}$. TPA values were calculated by graphing force and time plots. Values for hardness $(\mathrm{kg})$, springiness, cohesiveness, gumminess $(\mathrm{kg})$, and chewiness $(\mathrm{kg})$ were determined as described by Bourne (1978). 


\section{Sensory evaluation}

A trained 30 member panel consisting of researchers from the Department of Food Sciences and Biotechnology of Animal Resources at Konkuk University in Korea was used to evaluate the chicken frankfurters. Each chicken frankfurter was evaluated in terms of color, flavor, juiciness, tenderness, and overall acceptability. Chicken frankfurters were cooked to a center temperature of $75^{\circ} \mathrm{C}$, cooled to $21^{\circ} \mathrm{C}$, cut into quarters (length $\times$ diameter: $5 \times 25$ $\mathrm{mm}$ ), and served randomly to the panelists. Each sample was coded with a randomly selected 3-digit number. Sensory evaluations were performed under fluorescent lighting. Panelists were instructed to cleanse their palates with water between samples. The color $(1=$ extremely undesirable, $10=$ extremely desirable), flavor ( $1=$ extremely undesirable, $10=$ extremely desirable $)$, tenderness $(1=$ extremely tough, $10=$ extremely tender $)$, juiciness $(1=$ extremely dry, $10=$ extremely juicy), and overall acceptability $(1=$ extremely undesirable, $10=$ extremely desirable) of the cooked samples were evaluated using a 10-point descriptive scale. This analysis was conducted using the hedonic test described by Choi et al. (2010a).

\section{Statistical analysis}

All tests were conducted at least three times for each experimental condition, and mean values are reported. An analysis of variance was performed on all the variables measured using the general linear model procedure of the SAS statistical package (2008). Duncan's multiple range test $(p<0.05)$ was used to determine the differences among treatments.

\section{Results and Discussion}

\section{Proximate composition and energy value}

The proximate composition and energy values of the chicken frankfurters formulated with different amounts of pumpkin fiber are given in Table 2. Differences in moisture, fat, and ash content of the chicken frankfurters were significant compared to those of the control $(p<0.05)$. The moisture content of the chicken frankfurters samples containing pumpkin fiber was higher than the control without pumpkin fiber $(p<0.05)$. However, moisture content did not differ among pumpkin fiber treatments $(p>0.05)$, probably because the chicken frankfurters had pumpkin fiber added. These results agree with those reported by Choi et al. (2009), who found significantly increased moisture content in low-fat tteokgalbi with added dietary fiber, and adding rice bran fiber increased the water holding capacity of tteokgalbi. According to Choi et al. (2010b), adding dietary fiber increases the moisture content of meat emulsion systems, providing higher water retention and improved emulsion stability. Additionally, Garcia et al. (2002) indicated that wheat, oat, and fruit fiber increase the moisture content of fermented sausage, which was higher than that of the control due to high water retention of the fiber. Protein content was not significantly different between the control and treatments with added pumpkin fiber $(p>0.05)$. The fat content of chicken frankfurters was the highest in the control without added pumpkin fiber $(p<0.05)$, and the lowest in treatments with $3 \%$ and $4 \%$ added pumpkin fiber added $(p<0.05)$. Fat content may have been affected by the added pumpkin fiber, as moisture content relative increased. Similar trends in fat content were reported in a study by Choi et al. (2012) when different levels of Laminaria japonica fiber were added to reduced-fat pork patties. Choi et al. (2009) observed that adding rice bran fiber decreases the fat content of meat products related to increased moisture content. In general, some researchers have reported that dietary fiber produces emulsion meat products with lower fat content (Choi et al., 2009; Choi et al., 2010c; Fernández-Ginés et al., 2004; Lee et al., 2008). The ash content was higher in samples containing pumpkin fiber than that

Table 2. Proximate composition and energy value of chicken frankfurters formulations with varying amounts of added pumpkin fiber

\begin{tabular}{|c|c|c|c|c|c|}
\hline Parameters & Control $^{1)}$ & T1 & $\mathrm{T} 2$ & T3 & T4 \\
\hline Moisture (\%) & $55.64 \pm 0.83^{b}$ & $57.20 \pm 0.76^{\mathrm{a}}$ & $57.88 \pm 0.19^{\mathrm{a}}$ & $57.59 \pm 0.45^{\mathrm{a}}$ & $57.52 \pm 0.29^{\mathrm{a}}$ \\
\hline Protein $(\%)$ & $13.86 \pm 1.38$ & $13.21 \pm 0.92$ & $13.21 \pm 0.75$ & $13.21 \pm 0.75$ & $10.80 \pm 0.79$ \\
\hline Fat $(\%)$ & $27.23 \pm 0.77^{\mathrm{a}}$ & $27.00 \pm 0.20^{\mathrm{ab}}$ & $26.02 \pm 0.57^{b}$ & $24.85 \pm 0.49^{c}$ & $25.11 \pm 0.41^{\mathrm{c}}$ \\
\hline $\operatorname{Ash}(\%)$ & $2.24 \pm 0.04^{\mathrm{d}}$ & $2.30 \pm 0.05^{\mathrm{c}}$ & $2.38 \pm 0.13^{b}$ & $2.44 \pm 0.05^{\mathrm{ab}}$ & $2.50 \pm 0.05^{\mathrm{a}}$ \\
\hline Energy value (kcal/100g) & $304.77 \pm 1.75^{\mathrm{a}}$ & $297.22 \pm 2.04^{b}$ & $289.16 \pm 1.12^{\mathrm{c}}$ & $284.15 \pm 1.03^{\mathrm{d}}$ & $285.11 \pm 1.98^{d}$ \\
\hline
\end{tabular}

All values are mean \pm standard deviation of three replicates.

${ }^{\mathrm{a}-\mathrm{d}}$ Means within a row with different letters are significantly different $(p<0.05)$.

${ }^{1)}$ Control, chicken frankfurter without pumpkin fiber; T1, chicken frankfurter with $1 \%$ pumpkin fiber; T2, chicken frankfurter with $2 \%$ pumpkin fiber; T3, chicken frankfurter with 3\% pumpkin fiber; T4, chicken frankfurter with 4\% pumpkin fiber 
in the control, as pumpkin fiber has an ash content of $6.67 \%$. Similar results were obtained by Choi et al. (2010b) who studied the physicochemical properties of meat batter with added dietary fiber. Fernández-Ginés et al. (2004) reported that the ash content of low-fat sausage supplemented with dietary fiber from lemon albedo was higher than that in the control without lemon albedo. Many researchers have observed that ash content increases significantly when adding dietary fiber to meat products from natural sources, as natural dietary fiber contains minerals and vitamins (Choi et al., 2009; Choi et al., 2010b, 2012; Fernández-Ginés et al., 2004; Lee et al., 2008). The energy values of the chicken frankfurters ranged from 284.15 to $304.77 \mathrm{kcal} / 100 \mathrm{~g}$. The energy values were lower for treatments formulated with pumpkin fiber than those in the control $(p<0.05)$, as increasing pumpkin fiber levels decreased the energy value of the samples $(p<0.05)$. The energy values observed were similar to the fat content trends and may have been affected by the proximate composition (in particular fat content) of the chicken frankfurters. These results agree with those obtained by Choi et al. (2010a) for frankfurters with added rice bran fiber and by Grigelmo-Miguel et al. (1999) for low-fat high dietary fiber frankfurters. Turhan et al. (2005) reported that low-fat meat products with a hazelnut pellicle treatment had lower energy values than those of the control. Similar results were obtained by Cengiz and Gokoglu (2005) for sausage with added citrus fiber. These results showed that sausage with citrus fiber had significantly higher energy values than those of control sausages.

\section{pH and color}

Table 3 shows the $\mathrm{pH}, L^{*}$-values (lightness), $a^{*}$-values (redness), and $b^{*}$-values (yellowness) for chicken meat batter and chicken frankfurters formulated with various amounts of added pumpkin fiber. The $\mathrm{pH}$ of the chicken meat batter treatments was not significantly different between the control without pumpkin fiber and treatments with added pumpkin fiber $(p>0.05)$. The $\mathrm{pH}$ of the chicken frankfurters increased significantly by increasing the pumpkin fiber levels from 0 to $4 \%(p<0.05)$. These results may have been affected by the $\mathrm{pH}$ of pumpkin fiber (pH: 6.74). Lee et al. (2010) found that similar results, as the $\mathrm{pH}$ value of foods was higher for those formulated with pumpkin flour than that in the control. Choi et al. (2011) reported that the $\mathrm{pH}$ of meat products is higher with increased levels of added brown rice fiber due to minerals such as iron, phosphorus, and calcium. Furthermore, the $\mathrm{pH}$ was higher in the chicken frankfurters than that in the meat batter. Some researchers have reported that the $\mathrm{pH}$ of meat products increases with heating due to the imidazolium that is unfolded and exposed, which has basic activity due to histidine (Choi et al., 2009; Choi et al., 2010b; Choi et al., 2012; Lee et al., 2008).

The lightness, redness, and yellowness of the chicken meat batter and chicken frankfurters samples were significantly different based on the amount of added pumpkin fiber (Table 3). The lightness of the chicken meat batter and chicken frankfurters decreased significantly by increasing pumpkin fiber levels $(p<0.05)$. The redness of the meat batter and frankfurters was lower for treatments formulated with pumpkin fiber than that of the control $(p<0.05)$. The yellowness values of the meat batter and frankfurters were the lowest in the control without pumpkin fiber $(p<0.05)$, as the treatments with increasing added pumpkin fiber had increased yellowness values $(p<0.05)$. Similar results of decreased lightness and increased redness and yellowness with increasing pump-

Table 3. pH and color of chicken meat batters and frankfurters formulations with varying amounts of added pumpkin fiber

\begin{tabular}{|c|c|c|c|c|c|c|}
\hline Para & & Control $^{1)}$ & T1 & $\overline{\mathrm{T} 2}$ & T3 & T4 \\
\hline \multirow{4}{*}{ Meat batter } & $\mathrm{pH}$ & $6.35 \pm 0.02$ & $6.36 \pm 0.03$ & $6.37 \pm 0.03$ & $6.38 \pm 0.03$ & $6.36 \pm 0.04$ \\
\hline & $\mathrm{L}^{*}$-value & $83.19 \pm 0.93^{\mathrm{a}}$ & $83.46 \pm 0.73^{\mathrm{a}}$ & $81.14 \pm 0.54^{b}$ & $80.80 \pm 0.43^{b}$ & $79.44 \pm 0.90^{\mathrm{c}}$ \\
\hline & $a^{*}$-value & $2.92 \pm 0.25^{\mathrm{a}}$ & $0.54 \pm 0.27^{\mathrm{d}}$ & $0.67 \pm 0.34^{\mathrm{d}}$ & $0.73 \pm 0.12^{\mathrm{c}}$ & $0.93 \pm 0.17^{b}$ \\
\hline & $b^{*}$-value & $10.46 \pm 0.30^{\mathrm{e}}$ & $31.03 \pm 0.95^{\mathrm{d}}$ & $40.85 \pm 0.78^{c}$ & $44.18 \pm 0.55^{\mathrm{b}}$ & $50.06 \pm 1.06^{\mathrm{a}}$ \\
\hline \multirow{4}{*}{ Frankfurter } & $\mathrm{pH}$ & $6.42 \pm 0.03^{\mathrm{d}}$ & $6.45 \pm 0.02^{\mathrm{c}}$ & $6.46 \pm 0.02^{\mathrm{bc}}$ & $6.47 \pm 0.02^{b}$ & $6.49 \pm 0.02^{\mathrm{a}}$ \\
\hline & $\mathrm{L}^{*}$-value & $84.91 \pm 1.61^{\mathrm{a}}$ & $82.11 \pm 1.13^{\mathrm{b}}$ & $80.03 \pm 0.69^{c}$ & $78.42 \pm 0.61^{\mathrm{d}}$ & $77.72 \pm 0.22^{\mathrm{d}}$ \\
\hline & $a^{*}$-value & $0.55 \pm 0.16^{\mathrm{a}}$ & $-0.89 \pm 0.20^{\mathrm{c}}$ & $-0.74 \pm 0.33^{\mathrm{c}}$ & $-0.51 \pm 0.21^{b c}$ & $-0.03 \pm 0.22^{\mathrm{b}}$ \\
\hline & $b^{*}$-value & $11.67 \pm 1.17^{\mathrm{e}}$ & $28.24 \pm 0.49^{d}$ & $37.38 \pm 0.82^{\mathrm{c}}$ & $42.73 \pm 0.40^{\mathrm{b}}$ & $46.84 \pm 0.57^{\mathrm{a}}$ \\
\hline
\end{tabular}

All values are mean \pm standard deviation of three replicates.

${ }^{a-e}$ Means within a row with different letters are significantly different $(p<0.05)$.

${ }^{1)}$ Control, chicken frankfurter without pumpkin fiber; T1, chicken frankfurter with $1 \%$ pumpkin fiber; T2, chicken frankfurter with $2 \%$ pumpkin fiber; T3, chicken frankfurter with $3 \%$ pumpkin fiber; T4, chicken frankfurter with $4 \%$ pumpkin fiber 
kin levels were reported by Kim et al. (2004) for a pumpkin food in which chicken soup was added to the pumpkin. Lee et al. (2005) reported that cookies with added pumpkin powder have decreased lightness and increased redness and yellowness compared to those of control samples. These results were also in agreement with those of Woo et al. (2006) who reported decreased lightness and increased redness and yellowness by increasing dried sweet pumpkin powder levels in cake. Lee and Joo (2007) observed that muffins with added dried sweet pumpkin powder had lower lightness and higher redness and yellowness values than those of control samples. Thus, the lightness, redness, and yellowness values of chicken frankfurters were affected by the color of the pumpkin fiber.

\section{Cooking loss and emulsion stability}

Cooking loss and emulsion stability of the chicken frankfurters with various concentrations of pumpkin fiber are shown in Fig. 1. Chicken frankfurters with pumpkin fiber had less cooking loss compared to that in the control without pumpkin fiber $(p<0.05)$. Lee et al. (2008) reported similar results for meat emulsions with added dietary fiber from kimchi. Their emulsions containing kimchi fiber had cooking yields higher than those of the control. These results agree with Choi et al. (2012) who noted similar physicochemical characteristics of pork patties in which meat products were mixed with dietary fiber from Laminaria japonica. These results were due to cooking

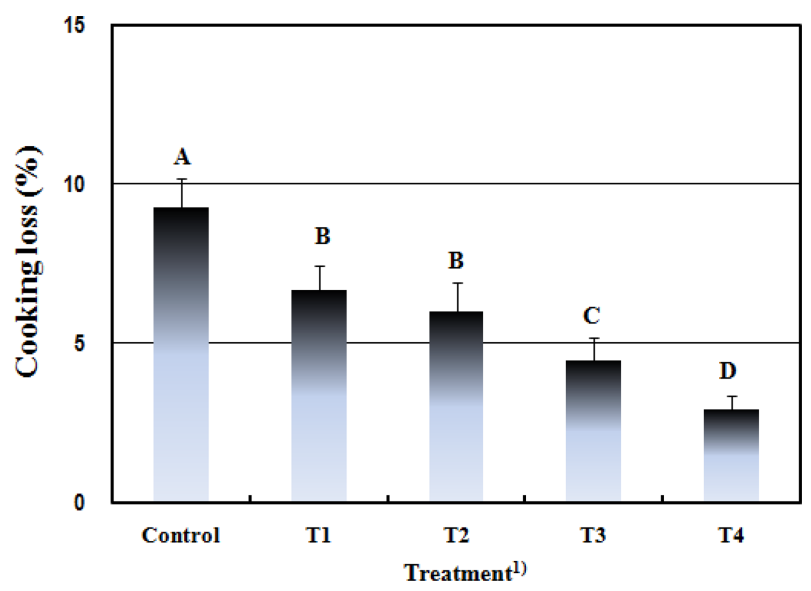

Fig. 1. Cooking loss of chicken frankfurters formulations with varying amounts of added pumpkin fiber. ${ }^{\mathrm{A}-\mathrm{D}}$ Means with different letters are significantly different $(p<0.05)$. ${ }^{1)}$ Control, chicken frankfurter without pumpkin fiber; T1, chicken frankfurter with $1 \%$ pumpkin fiber; T2, chicken frankfurter with $2 \%$ pumpkin fiber; T3, chicken frankfurter with $3 \%$ pumpkin fiber; $\mathrm{T} 4$, chicken frankfurter with $4 \%$ pumpkin fiber loss that occurs through the release of fat and moisture. Furthermore, the cooking loss of emulsion meat products with added dietary fiber improves as dietary fiber increases (Chin et al., 2004, Lee et al., 2008). Thus, dietary fiber is likely to be an important contributor to water holding capacity due to its high moisture absorption. Many researchers have found that dietary fiber from different sources or in combination can be used to decrease cooking loss by enhancing water and fat binding capacity (Choi et al., 2009; Choi et al., 2010c; Choi et al., 2011; Hughes et al., 1997; Lee et al., 2008; Turhan et al., 2005).

The chicken frankfurters formulated with different amounts of added pumpkin fiber had significant differences in emulsion stability (Fig. 2). According to Choi et al. (2011), emulsion stability is an index that estimates the physical properties of a final meat product. Because meat emulsions have high emulsion stability, they do not extrude water and fat during cooking. The control treatment had the highest water and fat exudation $(p<0.05)$. Increasing the pumpkin fiber levels from 0 to $4 \%$ decreased water and fat exudation significantly $(p<0.05)$. For these reasons, the ability of dietary fiber to bind water and strongly adsorb fat restricts molecular mobility (Choi et al., 2010b). Even reducing fat exudation, despite the decrease fat content and pumpkin fiber included in fat content $(4.83 \%)$ are associated with relative increased moisture content (Table 2). Choi et al. (2009) and Lee et

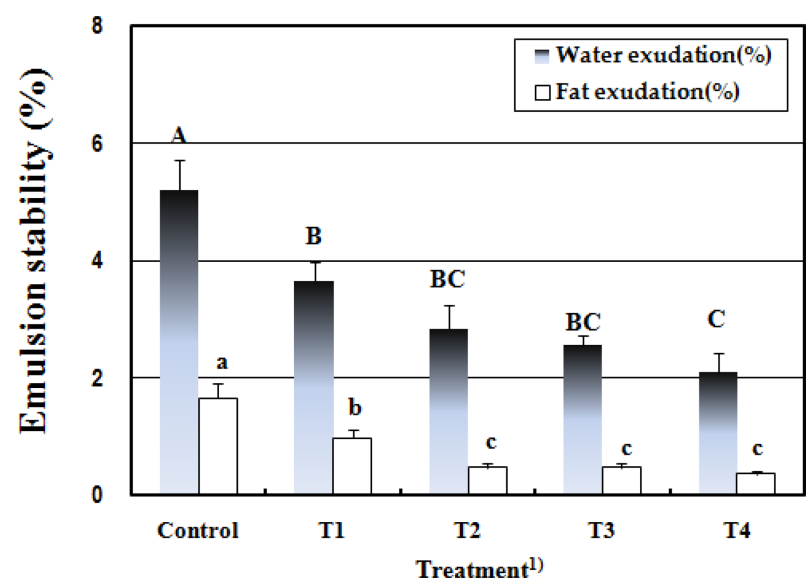

Fig. 2. Emulsion stability of chicken frankfurters formulations with varying amounts of added pumpkin fiber. ${ }^{\mathrm{A}-\mathrm{C}}$ Means with different letters are significantly different $(p<0.05)$. ${ }^{\mathrm{a}-\mathrm{c}}$ Means with different letters are significantly different $(p<0.05) .{ }^{1)}$ Control, chicken frankfurter without pumpkin fiber; T1, chicken frankfurter with $1 \%$ pumpkin fiber; T2, chicken frankfurter with $2 \%$ pumpkin fiber; T3, chicken frankfurter with $3 \%$ pumpkin fiber; T4, chicken frankfurter with $4 \%$ pumpkin fiber 
al. (2008) reported that adding dietary fiber from natural sources to meat emulsions improves emulsion stability and rheological properties. Thus, dietary fiber from pumpkin is useful because of its ability to enhance these properties in meat products.

\section{Apparent viscosity}

Adding pumpkin fiber levels affected the apparent viscosity of the chicken emulsion batter (Fig. 3). All treatments samples were thixotropic, with apparent viscosity values that decreased with rotation time. Adding pumpkin fiber to the formulation significantly affected the apparent viscosity values of the chicken meat batters. The control meat batter samples had the lowest maximum viscosity, whereas the samples supplemented with more pumpkin fiber had higher maximum viscosity values $(p<0.05)$. Similar trends in apparent viscosity were observed by Kim et al. (2004) when they added sweet pumpkin to chicken stock. These results indicate that adding sweet pumpkin

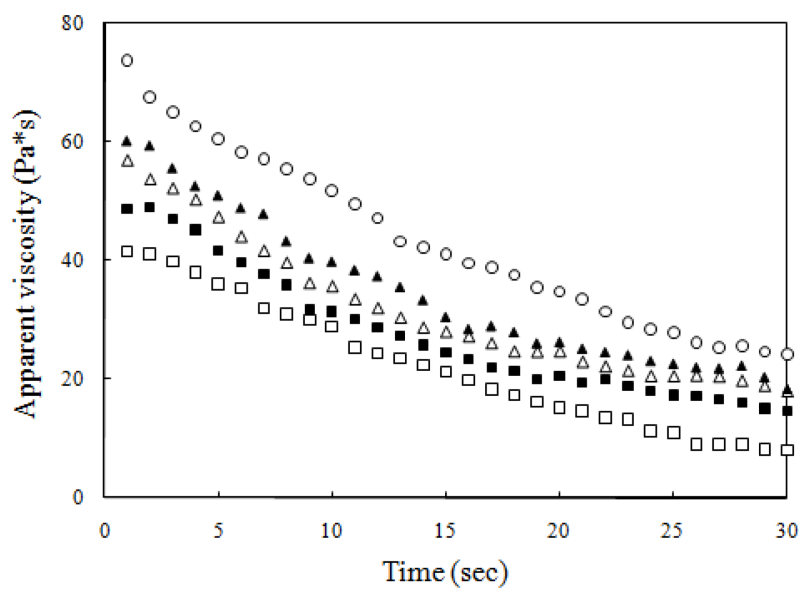

Fig. 3. Apparent viscosity of chicken frankfurters formulations with varying amounts of added pumpkin fiber. Control $(\square)$, chicken frankfurter without pumpkin fiber; $\mathrm{T} 1(\boldsymbol{\square})$, chicken frankfurter with $1 \%$ pumpkin fiber; T2 $(\triangle)$, chicken frankfurter with $2 \%$ pumpkin fiber; T3 $(\mathbf{\Delta})$, chicken frankfurter with $3 \%$ pumpkin fiber; T4 $(\bigcirc)$, chicken frankfurter with $4 \%$ pumpkin fiber results in higher apparent viscosity than that of the control. Lee et al. (2008) reported that elevating the viscosity of a meat emulsion is important for water binding capacity and dietary fiber content. This observation agrees with that of Choi et al. (2009) who observed that adding rice bran fiber increases the viscosity of low-fat meat emulsion systems. According to Yapar et al. (2006), high-fat emulsion sausages have increased emulsion viscosity, and the higher emulsion viscosity produces increased elasticity. In general, high viscosity of emulsion meat batter is not easily broken by emulsion stability (Choi et al., 2009; Shand, 2000). Thus, apparent viscosity values of meat batters can affect meat product qualities.

\section{Texture profile analysis (TPA)}

The textural properties of the chicken frankfurters are given in Table 4. The results indicated that pumpkin fiber level significantly affected the textural properties of the chicken frankfurters. The hardness was higher in the treatments with added pumpkin fiber compared to that in the control $(p<0.05)$. No significant difference in springiness was observed among the treatments tested $(p>0.05)$. The cohesiveness of the chicken frankfurters was the highest in the control and 1\% pumpkin fiber (T1) treatment $(p<0.05)$; however, the remaining treatments with added pumpkin fiber did not significantly differ $(p>0.05)$. The gumminess and chewiness of the chicken frankfurters increased significantly by increasing the pumpkin fiber levels from 0 to $4 \%(p<0.05)$. Woo et al. (2006) reported that food with added dried sweet pumpkin powder results in higher hardness, gumminess, and chewiness than those of the control, but that springiness did not differ significantly among the treatments. This result agrees with that of Choi et al. (2009) who studied the effects of rice bran fiber on textural properties of frankfurters, and with Luruena-Martinez et al. (2004) who observed the effects of locust bean/xanthan on the TPA of low-fat frankfurters. Garcia et al. (2002) reported that the hardness of

Table 4. Textural properties of chicken frankfurters formulations with varying amounts of added pumpkin fiber

\begin{tabular}{|c|c|c|c|c|c|}
\hline Parameters & (- Control ${ }^{1)}$ & "T1 & $\overline{\mathrm{TT} 2}$ & 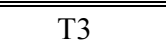 & 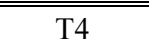 \\
\hline Hardness (kg) & $0.31 \pm 0.02^{\mathrm{c}}$ & $0.33 \pm 0.03^{b c}$ & $0.35 \pm 0.04^{\mathrm{abc}}$ & $0.36 \pm 0.03^{\mathrm{ab}}$ & $0.38 \pm 0.04^{\mathrm{a}}$ \\
\hline Springiness & $0.95 \pm 0.03$ & $0.95 \pm 0.03$ & $0.95 \pm 0.02$ & $0.93 \pm 0.02$ & $0.94 \pm 0.02$ \\
\hline Cohesiveness & $0.55 \pm 0.03^{\mathrm{a}}$ & $0.54 \pm 0.02^{\mathrm{a}}$ & $0.52 \pm 0.02^{\mathrm{ab}}$ & $0.51 \pm 0.03^{b}$ & $0.51 \pm 0.03^{\mathrm{b}}$ \\
\hline Gumminess (kg) & $0.16 \pm 0.02^{b}$ & $0.16 \pm 0.02^{\mathrm{b}}$ & $0.17 \pm 0.02^{\mathrm{b}}$ & $0.19 \pm 0.03^{\mathrm{a}}$ & $0.20 \pm 0.02^{\mathrm{a}}$ \\
\hline Chewiness (kg) & $0.15 \pm 0.02^{b}$ & $0.16 \pm 0.02^{\mathrm{b}}$ & $0.16 \pm 0.02^{b}$ & $0.18 \pm 0.03^{\mathrm{a}}$ & $0.19 \pm 0.02^{\mathrm{a}}$ \\
\hline
\end{tabular}

All values are mean \pm standard deviation of three replicates.

${ }^{a-c}$ Means within a row with different letters are significantly different $(p<0.05)$.

${ }^{1)}$ Control, chicken frankfurter without pumpkin fiber; T1, chicken frankfurter with $1 \%$ pumpkin fiber; T2, chicken frankfurter with $2 \%$ pumpkin fiber; T3, chicken frankfurter with 3\% pumpkin fiber; T4, chicken frankfurter with $4 \%$ pumpkin fiber 
Table 5. Sensory properties of chicken frankfurters formulations with varying amounts of added pumpkin fiber

\begin{tabular}{llllll}
\hline \hline \multicolumn{1}{c}{ Parameters } & Control $^{1)}$ & \multicolumn{1}{c}{ T1 } & \multicolumn{1}{c}{ T2 } & T3 & T4 \\
\hline Color & $8.58 \pm 0.83^{\mathrm{a}}$ & $8.05 \pm 0.93^{\mathrm{ab}}$ & $7.85 \pm 0.90^{\mathrm{ab}}$ & $7.62 \pm 0.71^{\mathrm{b}}$ & $7.54 \pm 0.53^{\mathrm{b}}$ \\
Flavor & $8.01 \pm 0.93$ & $8.12 \pm 0.64$ & $8.22 \pm 0.71$ & $8.19 \pm 0.64$ & $8.05 \pm 0.53$ \\
Tenderness & $7.52 \pm 0.29^{\mathrm{b}}$ & $7.75 \pm 0.45^{\mathrm{b}}$ & $8.17 \pm 0.53^{\mathrm{ab}}$ & $8.25 \pm 0.71^{\mathrm{a}}$ & $7.93 \pm 0.46^{\mathrm{b}}$ \\
Juiciness & $7.73 \pm 0.40^{\mathrm{c}}$ & $7.92 \pm 0.60^{\mathrm{c}}$ & $8.55 \pm 0.52^{\mathrm{ab}}$ & $8.82 \pm 0.75^{\mathrm{a}}$ & $8.09 \pm 0.73^{\mathrm{bc}}$ \\
Overall acceptability $^{\mathrm{c}}$ & $7.82 \pm 0.43^{\mathrm{ab}}$ & $7.98 \pm 0.61^{\mathrm{ab}}$ & $8.38 \pm 0.42^{\mathrm{a}}$ & $8.49 \pm 0.54^{\mathrm{a}}$ & $7.45 \pm 0.52^{\mathrm{b}}$ \\
\hline
\end{tabular}

All values are mean \pm standard deviation of three replicates.

${ }^{\text {a-c }}$ Means within a row with different letters are significantly different $(p<0.05)$.

${ }^{1)}$ Control, chicken frankfurter without pumpkin fiber; T1, chicken frankfurter with $1 \%$ pumpkin fiber; T2, chicken frankfurter with $2 \%$ pumpkin fiber; T3, chicken frankfurter with $3 \%$ pumpkin fiber; T4, chicken frankfurter with $4 \%$ pumpkin fiber

meat products increases with added cereal fiber, whereas Calvo et al. (2008) found that tomato peel increases the hardness of sausages. Normally, meat products with added dietary fiber from natural sources have improved textural properties (Choi et al., 2008; Choi et al., 2012; Cofades et al., 2000; Hughes et al., 1997; Lee et al., 2008), because the meat products containing added dietary fiber have improved water holding capacity and stronger binding ability. Additionally, meat products with added dietary fiber have different emulsion stability and gelling ability. Thus, the significant improvements in textural properties of meat products containing dietary fiber are due to adding dietary fiber.

\section{Sensory evaluation}

The sensory traits for chicken frankfurters with added pumpkin fiber are shown in Table 5. Each chicken frankfurter sample was evaluated for color, flavor, juiciness, tenderness, and overall acceptability. The control samples had the highest color scores $(p<0.05)$, compared to those of samples with added pumpkin fiber $(p<0.05)$. These results may be due to the presence of pumpkin fiber. The flavor score tended to be the highest in the $2 \%$ pumpkin fiber treatment (T2), but no differences were found for the flavor score $(p>0.05)$. The tenderness and juiciness scores were the highest in the 3\% pumpkin fiber treatment (T3) $(p<0.05)$. The overall acceptability score was the highest for 2 and 3\% added pumpkin fiber (T2 and T3) $(p<0.05)$. Woo et al. (2006) reported that adding sweet pumpkin powder affects the sensory properties of foods, which have higher overall acceptability than that of the control. These results agree with those reported by Kim et al. (2004) who found significantly higher overall acceptability in chicken stock with added sweet pumpkin. Similar results were obtained by Choi et al. (2012) for the influence of added Laminaria japonica fiber on the quality of meat products. They reported that reduced-fat patties with 1-3\% added Laminaria japonica fiber have higher overall acceptability compared to that of a control without added Laminaria japonica fiber. Choi et al. (2008) indicated that meat products containing dietary fiber from rice bran have higher sensory scores than those of controls. Thus, chicken frankfurters containing pumpkin fiber generated evaluation scores higher than those of the control.

\section{Conclusion}

We showed that adding pumpkin fiber had an important effect on the quality of chicken frankfurters. The chicken frankfurters had improved physicochemical, emulsion stability, viscosity, and textural properties. The chicken frankfurters formulated with $2 \%$ and $3 \%$ pumpkin fiber had higher overall acceptability than that of the control. Therefore, $2-3 \%$ pumpkin fiber was useful as a suitable dietary fiber source in chicken frankfurters, and adding pumpkin fiber into the formulation successfully improved the chicken frankfurters.

\section{Acknowledgements}

This work was supported by Ministry for Food, Agriculture, Forestry and Fisheries funded by the Korean Government (608001-05-2-SB310). The authors were also partially supported by the Brain Korean 21 (BK 21) Project from Ministry of Education and Human Resources Development (Republic of Korea).

\section{References}

1. Abiola, S. S., Kadiri, E. I., and Kareem, T. T. (2004) Effect of melon seed meal addition on some quality characteristics of chicken sausages. J. Sci. Food Agric. 84, 423-426.

2. Aleson-Carbonell, L., Fernandez-Lopez, J., Sayas-Barbera, E., Sendra, E., and Perez-Alvarez, J. A. (2003) Utilization of lemon albedo in dry-cured sausages. J. Food Sci. 68, 18261830 . 
3. AOAC (2000) Official methods of analysis. 17th ed, Association of Official Analytical Chemists, Washington, DC.

4. Bloukas, I. and Honikel, K. O. (1992) The influence of additives on the oxidation of pork back fat and its effect on water and fat binding in finely comminuted batters. Meat Sci. 32, 31-43.

5. Bourne, M. C. (1978) Texture profile analysis. Food Technol. 32, 62-66.

6. Caili, F., Haijun, T., Tongyi, C., Yi, L., and Quanhong, L. (2007) Some properties of an acidic protein-bound polysaccharide from the fruit of pumpkin. Food Chem. 100, 944947.

7. Calvo, M. M., Garcia, M. L., and Selgas, M. D. (2008) Dry fermented sausages enriched with lycopene from tomato peel. Meat Sci. 80, 167-172.

8. Cengiz, E. and Gokoglu, N. (2005) Changes in energy and cholesterol contents of frankfurter-type sausages with fat reduction and fat replacer addition. Food Chem. 91, 443-447.

9. Chin, K. B., Lee, H. L., Kook, S. H., Yoo, S. S., and Chun, S. S. (2004) Evaluation of various combinations of pork lean and water added on the physicochemical, textural and sensory characteristics of low-fat sausages. Food Sci. Biotechnol. 13, 481-485.

10. Choi, Y. S., Choi, J. H., Han, D. J., Kim, H. Y., Lee, M. A., Jeong, J. Y., Chung, H. J., and Kim, C. J. (2010a) Effects of replacing pork back fat with vegetable oils and rice bran fiber on the quality of reduced-fat frankfurters. Meat Sci. 84, 557563.

11. Choi, Y. S., Choi, J. H., Han, D. J., Kim, H. Y., Lee, M. A., Kim, H. W., and Kim, C. J. (2009) Characteristics of low-fat meat emulsion systems with pork fat replaced by vegetable oils and rice bran fiber. Meat Sci. 82, 266-271.

12. Choi, Y. S., Choi, J. H., Han, D. J., Kim, H. Y., Lee, M. A., Kim, H. W., Lee, J. W., Chung, H. J., and Kim, C. J. (2010b) Optimization of replacing pork back fat with grape seed oil and rice bran fiber for reduced-fat meat emulsion systems. Meat Sci. 84, 212-218.

13. Choi, Y. S., Choi, J. H., Han, D. J., Kim, H. Y., Lee, M. A., Lee, E. S., Jeong, J. Y., and Kim, C. J. (2008) Effects of rice bran fiber on quality of low-fat tteokgalbi. Food Sci. Biotechnol. 17, 959-964.

14. Choi, Y. S., Choi, J. H., Kim, H. W., Kim, H. Y., Song, D. H., Lee, M. A., Chung, H. J., and Kim, C. J. (2012) Effects of Laminaria japonica on the physic-chemical and sensory characteristics of reduced-fat pork patties. Meat Sci. 91, 1-7.

15. Choi, Y. S., Kim, H. W., Song, D. H., Choi, J. H., Park, J. H., Kim, M. Y., Lee, C. S., and Kim, C. J. (2011) Quality characteristics and sensory properties of reduced-fat emulsion sausages with brown rice fiber. Korean J. Food Sci. Ani. Resour. 31, 521-529.

16. Cofrades, S., Guerra, M. A., Carballo, J., Fernandes-Martin, F., and Colmenero, F. J. (2000) Plasma protein and soy fiber content effect on bologna sausage properties as influenced by fat level. J. Food Sci. 65, 281-287.

17. de Escalada Pla, M. F., Ponce, N. M., Stortz, C. A., Gerschenson, L. N., and Rojas, A. M. (2007) Composition and functional properties of enriched fiber products obtained from pumpkin (Cucurbita moschata Duchesne ex Poiret). LWT-Food Sci. Technol. 40, 1176-1185.

18. Fernández-Ginés, J. M., Fernández-López, J., Sayas-Barberá, E., Sendra, E., and Pérez-Álvarez, J. A. (2004) Lemon albedo as a new source of dietary fiber: Application to bologna sausages. Meat Sci. 67, 7-13.

19. Garcia, M. L., Dominguez, R., Galvez, M. D., Casas, C., and Selgas, M. D. (2002) Utilization of cereal and fruit fibers in low fat dry fermented sausages. Meat Sci. 60, 227-236.

20. Grigelmo-Miguel, N., Abadýìas-Serós, M. I., and MartýìnBelloso, O. (1999) Characterisation of low-fat high-dietary fibre frankfurters. Meat Sci. 52, 247-256.

21. Han, C. W., Park, W. J., and Seung, S. K. (2008) Optimization of preparation conditions and quality characteristics of sweet pumpkin stock. Korean J. Food Preserv. 15, 832-839.

22. Hwang, K. E., Choi, Y. S., Choi, J. H., Kim, H. Y., Kim, H. W., Lee, M. A., Chung, H. K., and Kim, C. J. (2011) Effect of Ganghwayaskssuk (Artemisia princeps Pamp.) on oxidative stability of deep fried chicken nuggets. Food Sci. Biotechnol. 20, 1381-1388.

23. Heo, S. J., Kim, J. H., Kim, J. K., and Moon, K. D. (1998) Processing of purees from pumpkin and sweet-pumpkin. Korean J. Postharvest Sci. Technol. 5, 172-176.

24. Hughes, E., Cofrades, S., and Troy, D. J. (1997) Effects of level, oat fiber and carrageenan on frankfurters formulated with 5, 12 and 30\% fat. Meat Sci. 45, 273-281.

25. Kim, J. M., Rho, Y. H., and Yoo, Y. J. (2004) Quality properties of cream soup added with chungdong pumpkin and sweet pumpkin. J. Korean Soc. Food Sci. Nutr. 33, 1028-1033.

26. Lee, M. A., Han, D. J., Jeong, J. Y., Choi, J. H., Choi, Y. S., Kim, H. Y., Paik, H. D., and Kim, C. J. (2008) Effect of kimchi powder level and drying methods on quality characteristics of breakfast sausage. Meat Sci. 80, 708-714.

27. Lee, M. H., Lee, S. Y., Lee, S. A., and Choi, Y. S. (2010) Physicochemical characteristics of rice flour sponge cakes containing various levels of pumpkin flour. Korean J. Food Nutr. 23, 162-170.

28. Lee, S. C., Prosky, L., and Devries, J. W. (1992) Determination of total, soluble, and insoluble dietary fiber in foods. Enzymatic-gravimetric method, MES-TRIS buffer: collaborative study. J. AOAC Int. 75, 395-416.

29. Lee, S. M. and Joo, N. M. (2007) The optimization of muffin with the addition dried sweet pumpkin powder. J. Korean Diet. Assoc. 13, 368-378.

30. Lee, S. M., Ko, Y. J., Jung, H. A., Paik, J. E., and Joo, N. M. (2005) Optimization of iced cookie with the addition of dried sweet pumpkin powder. Korean J. Food Culture 20, 516524.

31. Luruena-Martinez, M. A., Vivar-Quintana, A. M., and Revilla, I. (2004) Effect of locust bean/xanthan gum addition and replacement of pork fat with olive oil on the quality characteristics of low-fat frankfurters, Meat Sci. 68, 383-389.

32. SAS (2008) SAS/STAT Software for PC. Release 9.2, Statistical Analysis Systems Institute Inc., Cary, NC, USA.

33. Shand, P. J. (2000) Textural, water holding, and sensory 
properties of low-fat pork bologna with normal and waxy starch hull-less barley. J. Food Sci. 65, 101-107.

34. Turhan, S., Sagir, I., and Ustun, N. S. (2005) Utilization of hazelnut pellicle in low-fat beef burgers. Meat Sci. 71, 312316.

35. Vural, H., Javidipour, I., and Ozbas, O. O. (2004) Effects of interesterified vegetable oils and sugarbeet fiber on the quality of frankfurters. Meat Sci. 67, 65-72.

36. Woo, I. A., Kim, Y. S., Choi, H. S., Song, T. H., and Lee, S. K. (2006) Quality Characteristics of sponge cake with added dried sweet pumpkin powders. Korean J. Food Nutr. 19,
254-260.

37. Yang, H. S., Choi, S. G., Jeon, J. T., Park, G. B., and Joo, S. T. (2007) Textural and sensory properties of low fat pork sausages with added hydrated oatmeal and tofu as texture-modifying agents. Meat Sci. 75, 283-289.

38. Yapar, A., Atay, S., Kayacier, A., and Yetim, H. (2006) Effects of different levels of salt and phosphate on some emulsion attributes of the common carp (Cyprinus carpio L., 1758). Food Hydrocolloids 20, 825-830.

(Received 2012.1.7/Revised 2012.3.23/Accepted 2012.4.4) 